\title{
Luminescent Lanthanide(III) Carboxylate-phosphonates with Helical Tunnels
}

Si-Fu Tang, Jun-Ling Song, Xiu-Ling Li, and Jiang-Gao Mao*

\author{
Supporting Materials
}

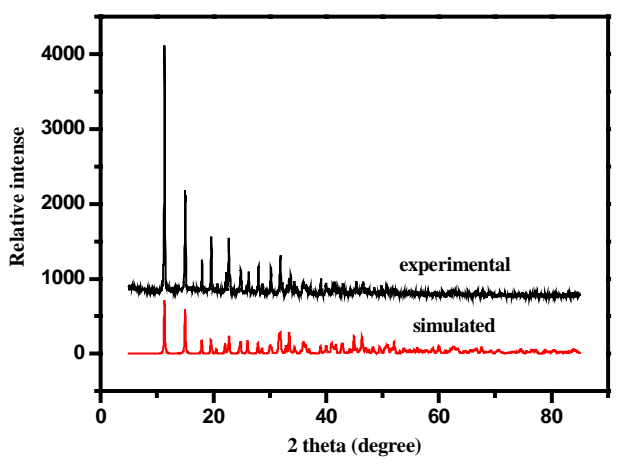

(a)

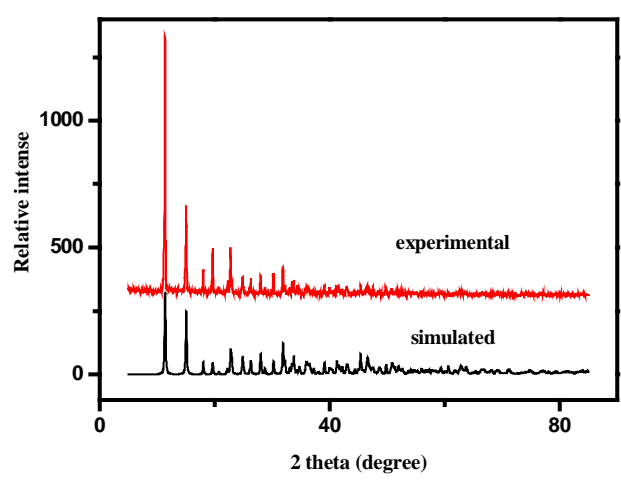

(c)

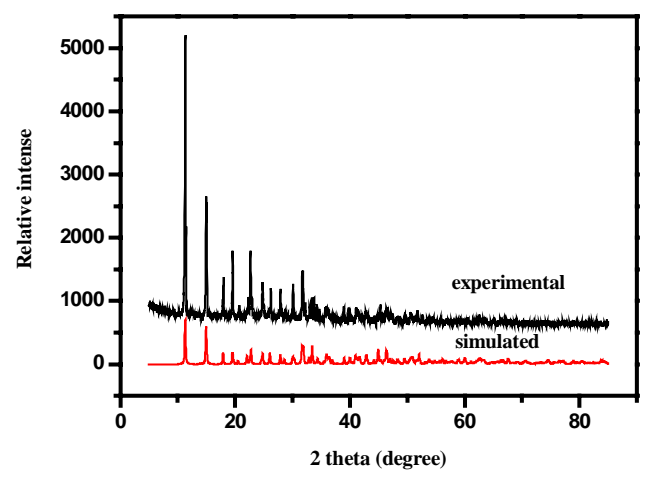

(b)

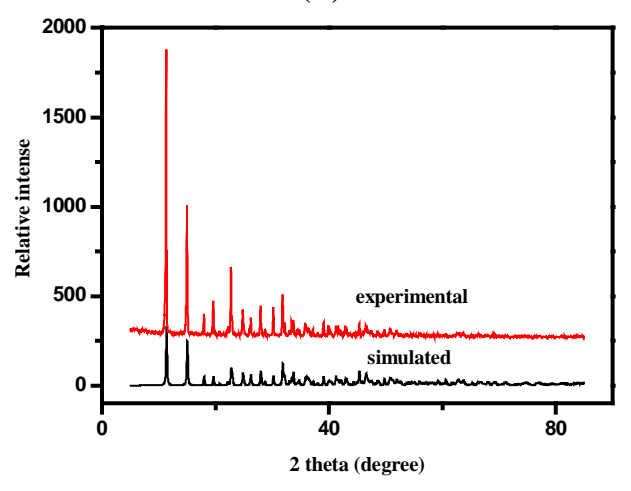

(d) 


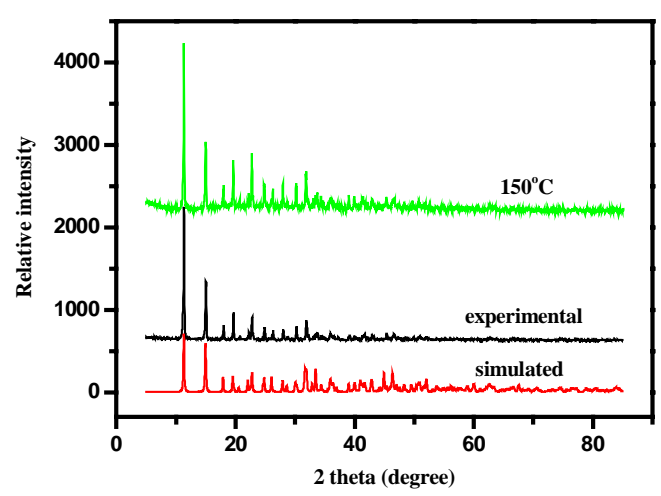

(e)

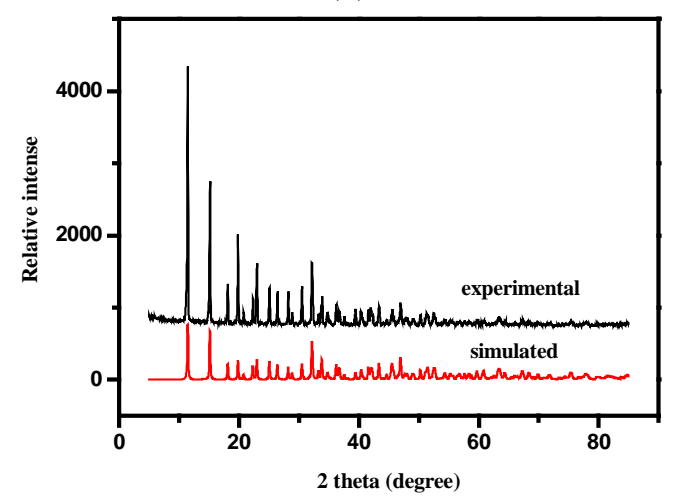

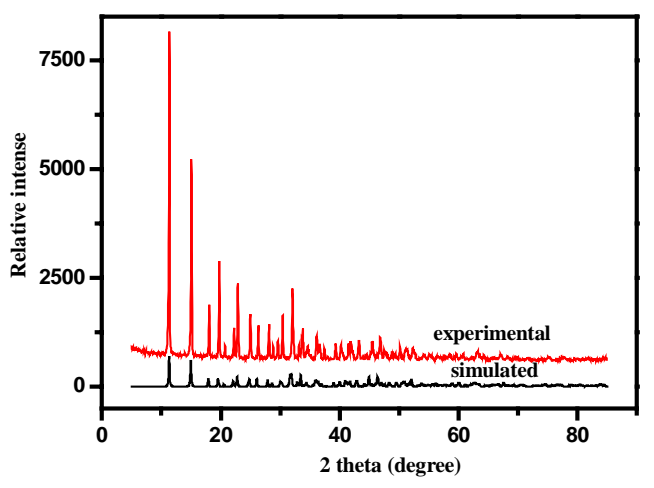

(f)

(g)

Figure S1. Experimental and simulated XRD powder patterns for compounds 1 (a), 2 (b), 3 (c), 4 (d), 5 (e), 6 (f) and 7 (g) 